\title{
Gorontalo
}

Journal of Government and Political Studies

Volume 4 - NO. 1 - April 2021

P-ISSN: 2614-2120 E-ISSN: 2614-2104

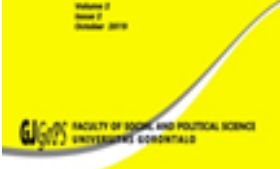

\section{Efektivitas Program Pemberdayaan Keterampilan Bagi Penyandang Disabilitas oleh Dinas Sosial Kecamatan Tambun Selatan, Kabupaten Bekasi}

\author{
Mulyanah, \\ Gili Argenti, \\ Moch Faizal Rizki \\ Program Studi Ilmu Pemerintahan, Fakultas Ilmu Sosial Dan Ilmu Politik \\ Universitas Singaperbangsa Karawang \\ Jl. HS. Ronggo Waluyo, Puseurjaya, Kec. Telukjambe Tim, \\ Kabupaten Karawang, Jawa Barat \\ mulyanaha1@gmail.com
}

Received: 05th February 2021; Revised: 07th March 2021; Accepted: 08th March 2021;

\begin{abstract}
This research is motivated by the large number of people with disabilites in Bekasi Regency, however the level of empowerment carried out by the Social Service has not been evenly distributed to person with disabilities in Bekasi Regency. This research method uses descriptive qualitative method, with data analysis using Milles and Huberman. The results of this study indicate that the effectiveness of the skills empowerment program for person with disabilities has not been effective, seen in the Integration variable in the precess of implementing the skill empowerment program, there is no socialization carried out either from the Social Service or from the South Tambun District, which has an impact on the lack of information for people variables of Facilities and Infrastructure provide during the preocess of empowering the skills of facilities and infrastucture, it was Social Service or Tambun District regarding the tools. That given toeach group were not used properly and there were some tools. That given by the office of social affairs is lost due to the lack of supervision carried out by the Social Service or Tambun District.
\end{abstract}

Keywords: Program effectivensess; skills empowerment; Social Service

\section{ABSTRAK}

Penelitian ini dilatarbelakangi oleh banyaknya jumlah penyandang disabilitas di Kabupaten Bekasi, namun tingkat pemberdayaan yang dilakukan oleh Dinas Sosial belum merata kepada penyandang Disabilitas yang ada di Kabupaten Bekasi. Metode penelitian ini menggunakan metode kualitatif deksriptif, dengan analisa data mengunakan Milles dan Huberman. Hasil penelitian ini menunjukan bahwa efektivitas program pemberdayaan keterampilan bagi penyandang disabilitas belum berjalan dengan efektiv dilihat pada variabel Integrasi dalam proses pelaksanaan program pemberdayaan keterampilan tidak ada sosialisasi yang dilakukan baik dari pihak Dinas Sosial ataupun dari Kecamatan Tambun Selatan, yang berdampak pada kurangnya informasi bagi penyadang disabilitas terkait dengan adanya program pemberdayaan keterampilan. Kemudian pada variabel Sarana dan Prasarana yang diberikan pada saat proses program pemberdayaan keterampilan sarana dan prasraana sudah memadai hanya saja kurang pengawasan baik dari Dinas Sosial atau Kecamatan Tambun terkait dengan alat-alat yang diberikan pada setiap kelompok tidak digunakan dengan baik dan 
ada sebagian alat-alat yang diberikan Oleh Dinas Sosial hilang karena kurangnya pengawasan yang dilakukan oleh Dinas Sosial ataupun Kecamatan Tambun.

\section{Kata kunci: Efektivitas program; pemberdayaan keterampilan; Dinas Sosial}

\section{PENDAHULUAN}

Penyandang disabilitas yang hidup di negara-negara berkembang hidup dibawah garis kemiskinan. Penyandang disabilitas juga lebih rentan terhadap kemiskinan disetiap negara, sehingga kerap kali menghadapi keterbatasan akses atas kesehatan, pendididkan, pelatihan dan pekerjaan yang layak. Di negaranegara Asia Tenggara, hampir semua negaranya termasuk Indonesia telah mengambil langkah kebijakan dan hukum dalam upaya melindungi hak-hak penyandang disabililitas (Arie, 2007). Di Indonesia sendiri penyandang disabilitas terus mengalami peningkatan, berdasarkan data dari Kementrian Sosial menurut hasil pendataan pada tahun 2017 atau survey jumlah penyandang disabilitas di beberapa provinsi di Indonesia, sebanyak 299.203 jiwa dan 10,5\% (31.327 jiwa) merupakan penyandang cacat berat yang mengalami hambatan dalam kegiatan sehari-hari. Sekitar $67,33 \%$ penyandang disabilitas dewasa tidak mempunyai keterampilan dan pekerjaan. Jenis keterampilan utama penyandang disabilitas adalah keterampilan pijat, pertukangan, petani, buruh dan jasa. Jumlah penyandang disabilitas laki-laki lebih banyak dari perempuan sebesar 57,96\%. Jumlah penyandang disabilitas tertinggi ada di Provinsi Jawa Barat $(50,900 \%)$ dan terrendah ada di Provinsi Gorontalo $(1,65 \%)$. Dari kelompok umur, usia 18-60 tahun menempati posisi tertinggi. Kecacatan yang paling banyak dialami adalah cacat kaki $(21,86 \%)$, mental retardasi $(15,41 \%)$ (Kementrian Sosial Rebulik Indonesia tahun 2017).

Pemahaman negatif tentang penyandang disabilitas antara lain berakar pada pola pikir pada masyarakat yang didominasi oleh konsep normalitas. Sikap dan prilaku diskriminasi berbasis atas dasar disabilitas bertentangan dengan hak-hak asasi manusia yang diakui secara universal diseluruh dunia (Ollerton \& Horsfall, 2013, p. 618). Pemberdayaan disabilitas dapat dilihat dari perspektif sosial berakar dari sudut pandang mengenai perlunya kemandirian pada penentuan nasib sendiri, menentukan pilihan dan pandangan disabilitas untuk mendorong peniadaan "penindasan sosial" disabilitas (Barnes \& Mercer, 2010). Pandangan demikian didasari dari terminologi disabilitas sebagai hambatan dari berbagai konteks untuk berpartisipasi secara penuh di masyarakat (Iudici, Favaretto, \& Turchi, 2019).

Setiap manusia memiliki hak dan kewajiban yang sama, hal ini berlaku pula bagi kelompok masyarakat yang memiliki gangguan mental, kelainan fisik dan kelainan intelektual, yang tidak bisa berfungsi secara normal atau yang lebih dikenal dengan istilah penyandang disabilitas (Undang-undang Nomor 8 Tahun 2016). Pemberdayaan bagi penyandang disabilitas adalah suatu strategi yang didasari oleh seberapa penting kapasitas manusia dalam upaya meningkatkan kemandirian serta meningkatkan kemampuan. Sebagai salah satu strategi pembangunan, pemberdayaan sendiri dapat diartikan sebagai suatu kegiatan yang digunakan iuntuk membantu masyarakat dalam menentukan pilihan dalam mengambil keputusan sserta tindakan dalam mengurangi hambatan-hambatan yang ada pada dirinya sendiri dengan meningkatkan kemampuan serta, rasa percaya diri (Safri Sholehuddin, 2020).

Tingkat pendidikan yang rendah serta keterampilan yang tidak memadai, ketika dihadapkan dengan tuntutan dunia usaha yang kiat kompetitip dari 
waktu ke waktu, membawa para penyandang disabilitas menuju kemiskinan. Penyandang disabilitas cenderung tidak diterima bekerja serta sulit untuk menciptakan usaha-usaha yang produktif. Di negara-negara berkembang seperti di Indonesia, permasalahan ini semakin jelas teramati. Selain bersaing mendapatkan pekerjaan yang layak, penyandang disabilitas di negara-negara berkembang dituntut untuk bersaing dengan para non disabilitas. Dalam iklim persaingan yang tidak sepadan tersebut, mudah diduga, para penyandang disabilitas biasanya keluar sebagai pihak yang terpinggirkan (Nurul Syoba, 2018).

Permasalahan seperti itu juga masi dirasakan oleh penyandang disabilitas di Kabupaten Bekasi. Meskipun sudah tercantum dalam Peraturan Daerah Kabupaten Bekasi 8 Nomor 10 Tahun 2012 tentang Penyelenggaraan Kesejahteraan Soial Pasal 16 ayat 1 dan 2 bahwa: Pemerintah Daerah mengupayakan seluruh penyandang masalah kecacatan untuk mendapatkan kebutuhan dasar atas pelayanan publik yang tidak diksriminatif, sehingga mampu mendorong kemandirian untuk aktif bersosialisasi, bermasyarakat, berbangsa dan bernegara. Dalam memberikan pelayanan kesejahteraan sosial bagi penyandang masalah kecacatan, Pemerintah Daerah mengupayakan: (a) memberikan kemudahan aksesbilitas penyandang kecacatan terhadap pelayanan publik antara lain penyediaan inprastruktur dan pelayanan sosial; (b) pelayanan rehabilitasi sosial dalam bentuk motivasi, perawatan, pembinaan, kewirausahaan, bimbingan sosial dan bantuan sosial".

Namun pada kenyataanya, dalam hal aksesbilitas ketersediaan sarana dan prasarana khusus penyandang disabilitas di Kabupaten Bekasi saat ini masi kurang diperhatikan. Hal itu dilihat dari tidak terpasangnya guiding blocks saat pembuatan trotoar di Cikarang Utara, sehingga pemerintah Kabupaten Bekasi dinilai kurang ramah terhadap keberadaan penyandang disabilitas di Kabupaten Bekasi. Padahal guiding blocks sangat berguna sebagai alur penentuan dan petunjuk bagi disabilitas khussunya tuna netra. Lebih lanjut Dinas Sosial Kapupaten Bekasi melansir jumlah penyandang disabilitas Tahun 2019 yaitu sebanyak 1,030 orang, hal tersebut tersebar di seluruh kecamatan yang ada di Kabupaten Bekasi. Jumlah penyandang disabilitas berdasarkan kecamatan di Kabupaten Bekasi Tahun 2019 yang dinaungi oleh Dinas Sosial Kabupaten Bekasi dapat dilihat pada tabel 1.1 sebagai berikut :

\begin{tabular}{ccccc}
\hline $\begin{array}{c}\text { Disabilitas } \\
\text { Mental }\end{array}$ & $\begin{array}{c}\text { Disabilitas } \\
\text { Fisik }\end{array}$ & $\begin{array}{c}\text { Disabilitas } \\
\text { Intelektual }\end{array}$ & $\begin{array}{c}\text { Disabilitas } \\
\text { Sensorik }\end{array}$ & Jumlah \\
\hline 155 & 439 & 58 & 378 & 1,030 \\
\hline
\end{tabular}

Sumber: Dinas Sosial Kabupaten Bekasi Tahun 2019

Pemberdayaan bagi penyandang disabilitas merupakan suatu upaya untuk meringankan beban mereka dalam mencapai kesejahteraanya. Proses pemberdayaan yang menekankan pada proses memberikan kemampuan dan mendorong atau memotivasi penyandang disabilitas agar dapat mempunyai kemampuan untuk menentukan piihan hidupnya. Memberdayakan penyandang disabilitas adalah upaya untuk meningkatkan harkat dan martabat penyandang disabilitas yang berada dalamkondisi lemah dan memandirikan disabilitas itu sendiri dengan mengandalkan kemampuannya sehingga dapat keluar dari kemiskinan dan keterbelakangan (Kartasasmita, 2007:1). 
Upaya kegiatan pemberdayaan yang dilaksanakan di Tambun Selatan oleh Dinas Sosial Kabupaten Bekasi selaku instansi yang memang menangani masalah penyandang disabilitas salah satunya berupa kegiatan pelatihan keterampilan. Kegiatan keterampilan dirasa memang sangat penting dan diperlukan bagi penyandang disabilitas, karena dengan adanya pelatihan keterampilan mereka bisa melatih kemampuan dan keterampilan yang mereka miliki sehingga mereka bisa melakukan sesuatu yang bermanfaat bagi mereka sendiri dan orang lain. Penyandang disabilitas bekerja tidak hanya untuk memenuhi kebutuhan hidupnya sehari-hari, melainkan bekerja untuk meningkatkan keterampilan sosial dalam bermasyarakat juga memberikan kesempatan kepada para penyandang disabilitas terjun seutuhnya sebagai masyarakat dalam ruang lingkup sosial (Mulyana., G. d. 2019).

Melihat beberapa persolan diatas mengenai penyandang disabilitas di Kabupaten Bekasi, dilihat dari kurang meratanya pelatihan keterampilan yang diberikan, sehingga masi terdapat penyandang disabilitas yang belum tersentuh penyuluhan mengenai pemberdayaan yang lebih efektiv yang bertujuan untuk meningkatkan kemandirian penyandang disabilitas di Kecamatan Tambun Selatan kabupaten Bekasi. Berdasarkan latar belakang permasalaan tersebut, maka peneliti tertarik mengkaji "Efektivitas Program Pemberdayaan Keterampilan Bagi Penyandang Disabilitas Oleh Dinas Sosial Di Kecamatan Tambun Selatan Kabupaten Bekasi”. Tujuan penelitian ini untuk mengetahui efektivitas program pemberdayaan keterampilan yang dilakukan oleh Dinas Sosial Kabupaten Bekasi di Kecamatan Tambun Selatan.

\section{METODE PENELITIAN}

Penelitian ini menggunakan metode deksriptif dengan pendekatan kualitatif. Metode deskriptif kualitatif adalah sebuah metode menganalisis data ditunjukan atau disajikan dengan menggambarkan atau menarasikan suatu fenomena sosial yang yang terjadi. Menurut Sugiono (2017:15) Metode deskriptif kualitatif adalah sebuah metode penelitian yang berdasarkan filsafat post positivisme yang biasanya digunakan untuk meneliti pada kondisi objek yang alamiah dimana peneliti berperan sebagai kunci. Dalam penelitian Efektivitas Program Pemberdayaan Keterampilan Bagi Penyandang Disabilitas Oleh Dinas Sosial Di Kecamatan Tambun Selatan Kabupaten Bekasi, peneliti menggunakan konsep efektivitas Dinas Sosial akan menjadi fokus penelitin, dimana konsep tersebut akan dianalisis dengan menggunakan teori efektivitas yang di kemukakan oleh Richart M. Steers (1985:53) dengan tiga dimensi yaitu pencapaian tujuan, Integritas dan adaptasi. Objek penelitian Dinas Sosial di Kabupaten Bekasi. Penentuan informant dalam hal ini ditembuh dengan mencari pihak yang terlibat langsung dalam proses program pemberdayaan keterampilan yakni, Kasi Rehabilitasi Penyandang Disabilitas, Staff Penyandang Disabilitas, Staff Kecamatan Tambun Selatan, dan 3 orang penyandang disabilitas. Penentuan informant ditentukan secara purposive berdasarkan berbagai pertimbangan yang dilakukan oleh peneliti. Menurut Sugiono (2017:137) terdapat dua utama yang mempengaruhi kualitas data hasil penelitian yaitu, instrument penelitian dan kualitas pengumpulan data. Kualitas pengumpulan data dipengaruhi oleh teknik pengumpulan data, dimana teknik pengumpulan data dapat dilakukan dengan Wawancara, Kuesioner, Observasi 
dan Studi Pustaka. Dalam penelitian ini peneliti menggunakan teknik analisa data model Miles dan Huberman (Sugiyono, 2017).

\section{HASIL DAN PEMBAHASAN}

Penelitian ini menggunaka teori Richard M. Steers (1985:53). Teori tersebut menggambarkan sebuah organisasi yang memiliki tujuan untuk keberhasilan program untuk mengukur dan menganalisa fenomea-fenomena yang me njadi kajian peneliti dengan tiga dimensi yaitu, pencapaian tujuan, integrasi, sarana dan prasarana. Maka peneliti ini telah melakukan penelitian ke lapangan dan hasil penelitian tersebut akan didesksripsika lebih rinci sebagai berikut:

\section{Pencapaian Tujuan}

Hasil penelitian ini menunjukan bahwa program pelatihan yang telah dilaksanakan oleh Dinas Sosial Kabupaten Bekasi di Kecamatan Tambun Selatan dapat dikatakan efektiv karena telah mencapai tujuan atau target yang telah ditentukan sebelumnya. Program pemberdayaan keterampilan bagi penyandang disabilitas yang dilaksanakan oleh Dinas Sosial bisa dikatakan telah sesuai dengan indikator tercapainya tujuan, hal ini ditunjukan dengan beberapa poin yang menyatakan bahwa tujuan program ini telah tercapai. Pertama dapat dikatakan efektiv karena program pelatihan ini disesuaikan dengan kebutuhan dan kemampuan para penyandang disabilitas. Kedua program pelatihan keterampilan di tunjang dengan dengan fasilitas dan alat-alat yang disediakan oleh Dinas Sosial kabupaten Bekasi seperti alat-alat sablon. Ketiga program ini pelatihan ini dilengkapi sumber daya yang handal seperti pemateri dan tenaga ahli sablon dan menjahit yang didatangkan langsung oleh Dinas Sosial, hal ini sangat menentukan berjalannya program pelatihan ini dengan baik, karena materi dan praktek yang tersampaikan dengan baik akan menghasilkan produk menjahit dan sablon yang baik pula.

Waktu yang di tentukan dalam proeses pemberdayaan yang dilakukan oleh Dinas Sosial di Kecamatan Tambun Selatan terbilang sangat minim dan sebentar, pemberdayaan program keterampilan hanya dilakukan dalam waktu tiga hari, dimana dalam waktu yang terbilang singkat parapenyandang disabilitas yang ada di Kecamatan Tambun Selatan dituntut harus bisa mengikuti dan memahami program keterampilan yang dilakukan. Pada tahun 2018-2019 Dinas Sosial telah memberikan pelatihan keterampil berupa pelatihan menjahit dan menyablon bagi penyandang disabilitas yang ada di Kecamatan Tambun Selatan Kabupaten Bekasi, proses pemberdayaan keterampilan diberikan secara bertahap, dengan harapan setelah diberikan pelatihan keterampilan tersebut para penyandang disabilitas terus berusaha mengasah kemampuan yang mereka miliki dan mengimplementasikannya. Berikut bentuk pelatihan yang sudah diberikan oleh Dinas Sosial kepada penyandang disabilitas Kabupaten Bekasi dapat di lihat pada tabel 1.2 sebagai berikut : 
Tabel 1.2 Keterampilan bagi penyandang disabilitas Kabupaten Bekasi

\begin{tabular}{llll}
\hline No & Jenis Pelatihan & $\begin{array}{c}\text { Tahun } \\
\text { Pelatihan }\end{array}$ & Jumlah Peserta \\
\hline 1. & Pelatihan Menjahit & 2018 & 20 Orang \\
\hline 2. & Pelatihan Sablon & 2019 & 30 Orang \\
\hline & Sumber: Dinas Sosial Kabupaten Bekasi Tahun 2019
\end{tabular}

Tercapainya tujuan suatu program merupakan suatu keberhasilan tersendiri karenanya motivasi untuk mencapai hal tersebut sangat penting. Dinas Sosial Kabupaten Bekasi sendiri telah mencapai target itu, karena jika berbicara hasil maka program pelatihan ini telah menghasilkan karya-karya dari tangan para penyandang disabilitas. Berdasarkan hasil wawancara mereka mengakui bahwa program pelatihan ini sangat berperan penting dalam meningkatkan kemampuan mereka, serta menjadikan modal untuk mereka bisa berkarya lebih baik lagi. Bagi penyandang disabilitas yang mempunyai niat, mau berusaha dan bersungguh-sungguh akan berhasil seperti salah satu penyandang disabiitas yang telah merasakan manfaat dari diadakannya program pemberdayaan keterampilan melalui proses yang tidak sebentar, kemudian dapat mendirikan usaha konveksi sejak tahun 2016.



Gambar 1.1 Produk hasil pembuatan masker peSnyandang disabilitas Sumber olahan peneliti tahun 2020

\section{Integritas}

Integritas yaitu mengukur terhadap tingkat kemampuan suatu organisasi, pengembangan konsesus dan komunikasi dengan berbagai macam organisasi lainya. Sosialisasi program pemberdayaan keterampilan merupakan titik awal yang menentukan keberhasilan program dalam mencapai suatu tujuannya. Oleh karena itu sosialisasi program harus dilakukan dengan cara-cara yang terencana dan sistematis dengan memberdayakan sumberdaya yang dimiliki oleh suatu organisasi agar tujuan yang direncanakan tercapai dengan baik.

Komunikasi Dinas sosial Kabupaten Bekasi dalam upaya pemberdayaan bagi penyandang disabilitas tentunya tidak hanya dengan aparaturnya saja, tetapi diperlukan pula suatu komunikasi berupa sosialisasi dengan penyandang disabilitas di Kecamatan Tambun Selatan Kabupaten Bekasi baik secara langsung ataupun tidak langsung, namun pada kenyataanya tidak adanya sosialisasi secara langsung yang di lakukan oleh Dinas Sosial ataupun 
Kecamatan Tambun terkait dengan program yang ingin dilaksanakan, informasi yang diberikan terkait dengan program pemberdayaan keterampilan hanya dilakukan dengan pertemuan antara ketua penyandang disabilitas kemudian informasi disampaikan di perkumpulan penyandang disabilitas yang ada di Kabupaten Bekasi.

\section{Adaptasi}

Pada indikator adaptasi berbagai hal yang berlaitan dengan proses penyelelarasan suatu individu terhadap perubahan-perubahan yang terjadi di lingkungannya. Adaptasi terdiri dari beberpa faktor, yaitu : (1) peningkatan kemapuan (2) sarana dan prasarana. Berkaitan dengan adaptasi peningkatan kemampuan disini para staff dari Dinas Sosial Kabupaten Bekasi mengikuti pelatihan guna meningkatkan kemampuan untuk dapat membantu mengefektivkan kinerja staff dalam memberdayakan penyandang disabilitas, namun para staff Dinas Sosial disini tidak mengikuti pelatihan guna meningkatkan kemampuannya karena memang yang memberikan keterampilan pada saat proses pemberdayaan baik secara materi ataupun prakteknya Dinas Sosial mendatangkan langsung instruktur yang memang ahli dibidangnya.

Pada indikator sarana dan prasarana sudah memadai dengan didukung oleh anggaran dari pemerintah terkait dengan pemberdayaan keterampilan Dinas Sosial telah menyediakan mulai dari tempat, alat-alat yang dibutuhkan oleh penyandang disabilitas, walaupun pemberdayaan butuh jangka waktu panjang tetapi para penyandang disabilitas mampu untuk mengikuti proses pemberdayaan tersebut. Kedepannya mereka yang mengasah kemampuan yang mereka miliki karena Dinas Sosial hanya sebatas memberikan dasarnya saja.

\section{PENUTUP}

Berdasakan hasil penelitian mengenai Efektivitas Program Pemberdayaan Keterampilan Bagi Penyandang Disabilitas Oleh Dinas Sosial di Kecamatan Tambun Selatan dapat ditarik kesimpulan: pemberdayaan bagi penyandang disabilitas sudah dikatakan efektiv dilihat dari indikator pecapaian tujuan dimana program keterampilan sudah sesuai dengan target yang telah di tentukan, hanya saja program keterampilan belum sepenuhnya dapat dirasakan oleh seluruh penyandang disabilitas yang ada di Kabupaten Bekasi, pada tahun 2018-2019 jumlah peserta hanya terdiri dari 20-30 orang. Apabila dibandingkan dengan jumlah keseluruhan penyandang disabilitas di Kabupaten Bekasi, jumlah penyandang disabilitas yang diberikan pelatihan tersebut masi sangat minim dan jauh dari jumlah penyandang disabilitas di Kabupaten Bekasi.

Saran yang dapat peneliti berikan pada setiap dimensi Efektivitas Program pemberdayaan yang dikemukakan Richard M. Steers (1985:53) adalah sebagai berikut: Pencapaian tujuan dilihat dari segi kurun waktu bahwa terkait dengan diadakannya sebuah program pemberdayaan dibutuhkan waktu jangka panjang agar program pemberdayaan dapat berjalan efektiv. Integrasi dalam menjalankan suatu program agar tercapainya tujuan sangat diperlukan untuk mengadakan sosialisasi terlebih dahulu, agar para penyandang disabilitas lebih memahami tentang program yang akan dilaksanakan dan mendapatkan informasi yang akurat dari Dinas Sosial langsung terkait adanya programprogram yang akan dilaksanakan. Adaptasi terkait dengan sarana dan prasarana harus terus ditingkatkan lagi baik dari segi tempat ataupun alat-alat 
yang dibutuhkan oleh penyandang disabilitas, serta perlu pengawasan lebih lanjut minimal 3 bulan sekali setelah program telah selesai dilaksanakan agar dapat melihat sejauh mana perkembangan kemampuan yang mereka miliki serta melihat alat-alat yang diberikan untuk pemberdayaan dapat digunakan dengan baik dan tidak disalah gunakan.

\section{DAFTAR PUSTAKA}

Sugiyono, 2007. Metode Penelitian Kualitatif, Kualitatif dan R\&D. Alfabet

Anwar, 2007. Manajemen Pemberdayaan Perempuan (Perubahan Sosial Melalui Pembelajaran Vocational Skill Pada Keluarga Nelayan. Bandung. Alfabeta.

Streers, M Richard. Efektivitas Organisasi. Jakarta: Erlangga 1985 hal 53

Syobah, Nurul. Sy. 2018. Pemberdayaan Penyandang Disabilitas Di Provinsi Kalimantan Timur. Jurnal Penelitian Ilmu Sosial dan Keagamaan Islam Vol 15, No 22018 Doi: http://dx. Doi.org/10.19105/nuansa.v15i2.2057.

Horsfall. D. \& Ollerton. (2013). Rights to research: untilizing the Convention on the Rights of Persons with Disabilities as an inclusive participatory action research tool. Disability \& Society, 28 (5), 616-630. Doi: 10. 1080/09687599.2012.717881

Turchi, G. P \&, A., Favaretto, G. (2019). Community perspective: How volunteers, professionals, families and the general population construct disability: Social, clinical and health implications. Disability and Health Journal, 12(2) 171-179. https://Doi.org/10.1016/j.dhjo.2018.11.014.

Geminastiti, Purinami dan Nanang Mulyana. Pemberdayaan Disabilitas dalam dunia kerja. Jurnal Pekerjaan Sosial 1, No. 3 (2019). https: / / Doi.org/ 10.24198/focus.v1i3.20499.

Safri, Sholehuddin. 2020. Corporate Social Responsibiity (CSR) Alfamart Dalam Mempekerjakan Penyandang Disabilitas. Jurnal Prosoding Penelitian dan Pengabdian Kepada

Masayarat. https://doi.org/10.24198/ippm.v712.29054.

Kartiko, Wahyu. 2019. Studi Perbandingan Perlindungan Hak Penyandang Disabilitas Di Indonesia Dan Asia Tenggara. Jurnal Polinter Prodi Imlu Politik FISIP UTA 45 Jakarta Vol. 4 No. 2 (September 2019).

Hayati, Suhailah. 2018. Peran Dinas Sosial Dalam Pemberdayaan Penyandang Disabilitas Di Kota Banjai. Jurnal Pemberdayaan Masyarakat. Volume 6 No. 2 Tahun 2018.

Kementrian Sosial Republik Indonesia: www.kemensos.go.id. Hasil Pendataan tahun 2017/survey Jumlah Penyandang Cacat dibeberapa Provinsi di Indonesia. Diakses Pada 20 November 2020.

Peraturan Daerah Kabupaten Bekasi 8 Nomor 10 Tahun 2012 tentang Penyelenggaraan Kesejahteraan Soial Pasal 16 ayat 1 dan 2

Undang-undang Republik Indonesia Nomor 8 Tahun 2016 Tentang Penyandang Disabilitas. 